http://dx.doi.org/10.12775/szhf.2018.019

\author{
Joanna Dorota ZegzuŁa-Nowak
}

Uniwersytet Zielonogórski, Zielona Góra, Polska

E-MAIL: JOANNA_ZEGZULA@VP.PL

\title{
Jan Łukasiewicz jako nauczyciel, mentor i inspirator twórczej aktywności Mieczysława Wallisa
}

Jan Łukasiewicz to jeden z głównych przedstawicieli szkoły lwowsko-warszawskiej, którego dokonania naukowe (szczególnie koncepcja logiki wielowartościowej) przyniosły mu światowy rozgłos i przyczyniły się do popularyzacji filozofii polskiej na forum międzynarodowym ${ }^{1}$. Okazuje się, że był on także niezwykle charyzmatycznym, wpływowym i inspirującym nauczycielem akademickim, który wykształcił wielu wybitnych rodzimych intelektualistów ${ }^{2}$. Jednym z nich był Mieczysław Wallis, który po doktoracie zajmował się przede wszystkim krytyką literacką, estetyką oraz historią i teorią sztuki³ . Co ważne, ten niezwykle wszechstronny i twórczy uczeń Łukasie-

${ }^{1}$ Por. J. Jadacki, P. Surma, Posłowie. Jan Łukasiewicz - osoba i dzieło, [w:] J. Łukasiewicz, Pamiętnik, Wyd. Semper, Warszawa 2013, s. 109.

${ }^{2}$ Kunszt pedagogiczny Łukasiewicza doceniali także jego uczniowie, np. M. Ossowska pisała o nim następująco: „trudno wątpić, że to był człowiek pod względem dydaktycznym rzadko uzdolniony i że mu bardzo dużo zawdzięczamy". Intymny portret uczonych. Korespondencja Marii i Stanisława Ossowskich, wybór, oprac. i wprow. E. Neyman, Wyd. Sic!, Warszawa 2002, s. 531.

${ }^{3}$ Wallis przez wiele lat był związany z powstałym po wojnie Uniwersytetem Łódzkim, gdzie kierował najpierw Katedrą Estetyki, a następnie Katedrą Historii Sztuki, której był współtwórcą. W tamtejszym środowisku akademickim przez wiele lat wyróżniał się niezwykle 
wicza, pozostawił po sobie obszerną spuściznę rękopiśmienną (obejmującą kilka tysięcy stron notatek, wspomnień, korespondencji). Nie jest ona jednak znana szerszemu gronu. Bywa jedynie fragmentarycznie cytowana w nielicznych dziełach monograficznych poświęconych temu filozofowi, wydanych np. przez Teresę Pękalę ${ }^{4}$ Znajduje się ona w zbiorach Połączonych Bibliotek Wydziału Filozofii i Socjologii UW, Instytutu Filozofii i Socjologii PAN oraz Polskiego Towarzystwa Filozoficznego w Warszawie, gdzie po śmierci uczonego przekazała ją jego synowa - Elżbieta Grabska-Wallis. Wśród tych archiwaliów znajdują się także nieznane materiały poświęcone bezpośrednio Janowi Łukasiewiczowi. Zapiski te stanowią niezwykle unikatowe, a przy tym cenne źródło wiedzy zarówno o samym Janie Łukasiewiczu (jego poglądach, aparycji, osobowości i zainteresowaniach naukowo-badawczych), jak i wpływie, jaki wywarł on na sylwetkę naukową samego autora. Warto podkreślić, że ich niewątpliwym atutem jest to, że są to wspomnienia osoby z najbliższego otoczenia autora rozprawy $O$ zasadzie sprzeczności u Arystotelesa. Jest to kopalnia wiedzy zarówno o relacji łączącej obu myślicieli oraz specyfice ówczesnego rodzimego środowiska naukowego, jak i oryginalne świadectwo samej epoki, w której obaj żyli i tworzyli.

Podążając zatem śladem Wallisowskich zapisków, warto podjąć się próby nie tylko odtworzenia drogi jego intelektualnego rozwoju i ewolucji zainteresowań badawczych, ale także, a może przede wszystkim określenia roli, jaką $\mathrm{w}$ tym procesie odegrała umysłowość Jana Łukasiewicza. Wpływ warszawskiego uczonego oraz intelektualnego klimatu całej szkoły lwowsko-warszawskiej na ostateczny kształt postawy naukowej Wallisa był bowiem niezwykle rozległy - rozciągał się od metodologicznych wytycznych dotyczących pro-

ożywioną działalnością założycielską, organizatorską, naukową i dydaktyczną: „stworzył kierunek historii sztuki, kształtując tym samym środowisko przyszłych badaczy, pracowników naukowych, muzealników, konserwatorów [...]”. Był on także promotorem ponad 20 prac magisterskich oraz 4 prac doktorskich z zakresu estetyki oraz historii sztuki. Okazał się również niezwykle płodnym twórcą, w jego dorobku naukowym znajduje się bowiem ponad 900 pozycji: książek, artykułów, recenzji, sprawozdań. W. Nowakowska, Sylwetki łódzkich uczonych. Profesor Mieczysław Wallis, Łódzkie Towarzystwo Naukowe, zeszyt 59, Łódź 2001, s. 11. Więcej o zainteresowaniach badawczych i działalności naukowej Wallisa pisze także J. Pelc; zob. tenże, Wspomnienia pozgonne o Mieczystawie Wallisie i Tadeuszu Wójciku, „Studia Semiotyczne” 1977, nr 7, s. 5-6.

${ }^{4}$ Por. T. Pękala, Estetyka otwarta Mieczysława Wallisa, Wyd. Instytut Kultury, Warszawa 1997, ss. 204 oraz taż, Świat jako przedmiot estetyczny. Wprowadzenie, [w:] M. Wallis, Wybór pism estetycznych, Towarzystwo Autorów i Wydawców Prac Naukowych Universitas, Kraków 2004. 
wadzenia pracy naukowej, poprzez inspirację merytoryczną z zakresu filozofii, aż po wyłonienie się w jego rozważaniach nowych obszarów badawczych $\mathrm{z}$ zakresu zastosowania semantyki w teorii i historii sztuki. Stymulacja intelektualna, której Łukasiewicz poddawał stale swego ucznia, doprowadziła zatem do odrzucenia przez Wallisa postulatów szkoły heidelberskiej, pod której silnym wpływem pozostawał we wczesnej młodości i pozwoliła na ostateczne ukonstytuowanie się jego dojrzałej postawy naukowej, a także skrystalizowała horyzonty badawcze na dalsze dziesięciolecia jego pracy twórczej. I choć ostatecznie jego zainteresowania badawcze obrały odmienny od Łukasiewicza kurs badawczy - zogniskowały się wokół rozważań estetycznych, aksjologicznych i poświęconych analizom z zakresu teorii sztuki, to świadczy to tylko o tym, że warszawskiemu środowisku naukowemu udało się osiągnąć najwyższy cel dydaktyczny - ukształtować swego ucznia na niezależnego uczonego o własnej wizji i predylekcjach intelektualnych, stanowiącego „człowieka głęboko i całkowicie oddanego wartościom, w które wierzył”.

\section{Pobyt Mieczysława Wallisa na Uniwersytecie w Heidelbergu i jego pierwsze inspiracje intelektualne}

Zanim jednak Mieczysław Wallis trafił na Uniwersytet Warszawski i został uczniem Jana Łukasiewicza przebywał na Uniwersytecie w Heidelbergu, gdzie w latach 1913-1914 rozwijał swe zainteresowania naukowe, przede wszystkim: przyrodniczo-biologiczne oraz z zakresu nauk ścisłych. Uczęszczał tam na wykłady z systematyki i fizjologii roślin oraz fizyki eksperymentalnej. To tam zetknął się także po raz pierwszy z filozofią, wybierając przedmioty takie jak: historia filozofii starożytnej i średniowiecznej oraz filozofia religii. Co ważne, uniwersytet ten stanowił wówczas jeden $\mathrm{z}$ głównych ośrodków neokantyzmu. Młody Wallis znalazł się wówczas pod wpływem poglądów tamtejszych uczonych, przede wszystkim za sprawą swego charyzmatycznego nauczyciela Wilhelma Windelbanda ${ }^{6}$. Filozof ten był czołowym reprezentan-

\footnotetext{
${ }^{5}$ J. Białostocki, Wspomnienie pośmiertne. Mieczysław Wallis 1895-1975 (Przemówienie wygłoszone nad grobem w dniu 30 października 1975 r.), [w:] M. Wallis, Sztuki i znaki. Pisma semiotyczne, PIW, Warszawa 1983, s. 339.

${ }^{6}$ We wspomnieniach Wallisa znajdujemy także dość szczegółowy opis aparycji heidelberskiego wykładowcy o następującej treści: „Był barczysty, nieco pochylony. Miał długą roz-
} 
tem tzw. neokantowskiej szkoły badeńskiej. W Heidelbergu wykładał m.in. filozofię antyczną, średniowieczną i nowożytną ${ }^{7}$. Co ważne, to właśnie on był pierwszym Wallisowskim intelektualnym inspiratorem, który rozbudził $\mathrm{w}$ nim ambicje poznawcze - przede wszystkim dążenie zmierzające do zadośćuczynienia pragnieniu dotarcia do wiedzy pewnej. To za sprawą Windelbanda właśnie Wallis zainteresował się Kantowską epistemologią i docenił wagę pytania o istotę i granice poznania. Z Heidelberga wyniósł on uznanie dla koncepcji filozofa z Królewca, które później upadło pod wpływem ognia ostrej krytyki ze strony Łukasiewicza. Wallis pisał o Windelbandzie następująco:

Był wielbicielem Kanta, ale twierdził, że »rozumieć Kanta znaczy wyjść poza niego«. Podnosił jednostronność kantowskiej teorii poznania, zorientowanej wyłącznie według matematyki i matematycznego przyrodoznawstwa i domagał się jej uzupełnienia pod względem historii; głosił prymat rozumu praktycznego, interpretował Kanta aksjologicznie $[\ldots]^{8}$.

Stanowisko to przytacza także i rozjaśnia nieco T. Gadacz, powołując się na słowa samego Windelbanda, który argumentował następująco:

My wszyscy, którzy filozofujemy w wieku XIX, jesteśmy uczniami Kanta. Ale nasz dzisiejszy "powrót« do niego nie może być tylko odnowieniem historycznie uwarunkowanej postaci, w jakiej przedstawił on ideę filozofii krytycznej. Im wyraźniej ujmuje się antagonizm występujący pomiędzy różnymi motywami, jego myślenia, tym bardziej odnajduje się w tym środek służący do rozpracowania stworzonych przez niego problemów własnych rozwiązań. Zrozumieć Kanta oznacza wykroczyć poza niego'9

łożystą brodę. Na katedrze, w czasie wykładu, wydawał mi się wcieleniem mędrca. Był już schorowany i niekiedy z trudem chwytał powietrze. Dlatego prosił studentów, by nie witali go, jak to było w zwyczaju, szarganiem, gdyż to wbija pył i kurz. Mówił płynnie długimi, zaokrąglonymi okresami. Słuchałem u niego historię filozofii do Kanta. To, co mówił, pokrywało się na ogół z tym, co było w jego podręcznikach. Czasem jednak wtrącał pewne uwagi polemiczne lub żarty. Materiały Archiwalne M. Wallisa, Archiwum Połączonych Bibliotek Wydziału Filozofii i Socjologii UW, Instytutu Filozofii i Socjologii PAN oraz Polskiego Towarzystwa Filozoficznego, teczka Rps, 10, T. VI, k. 19.

${ }^{7}$ Por. tamże, k. 18.

8 Tamże, k. 24.

${ }^{9}$ W. Windelband, Präludien. Aufsätze und Reden zur Philosophie und ihrer Geschichte, t. 1, Tübingen 1924, s. 151, [za:] T. Gadacz, Historia filozofii XX wieku. Nurty, t. 2, Wyd. Znak, Kraków 2009, s. 211. 
Ponadto należy podkreślić, że wykłady Windelbanda zainicjowały inną ważną w aktywności twórczej Wallisa problematykę. Dały mu bowiem asumpt do namysłu nad istotą i sposobem istnienia wartości, zagadnienia te zaś stały się w późniejszej pracy naukowej Wallisa główną osnową jego rozważań ${ }^{10}$.

Wypowiedzi autora dzieła Przeżycie i wartość dotyczące pobytu w Heidelbergu, wskazują niewątpliwie, że niezmiernie cenił on Windelbanda zarówno jako uczonego, jak i człowieka. Pisał o nim na przykład:

Windelband, znakomity historyk filozofii starożytnej i nowożytnej, autor podręcznika historii filozofii, przedstawiającego dzieje zagadnień filozoficznych i monografii o Platonie, poza tym twórca rozróżnienia nauk idiograficznych i nomotetycznych. Był głową jednego z odłamów neokantyzmu, tzw. badeńskiej lub południowo-zachodnio-niemieckiej szkoły filozoficznej ${ }^{11}$.

Dalej wspominał też: „Jako człowiek Windelband był niezmiernie sympatyczny - uprzejmy i ujmujący w obejściu [...], pozbawiony jakichkolwiek uprzedzeń narodowościowych lub wyznaniowych [...]"12. Analizując Wallisowskie rękopisy poświęcone W. Windelbandowi, można zatem założyć, że to właśnie ten uczony był jego pierwszym ważnym intelektualnym mentorem, który nie tylko rozbudził jego zainteresowania filozoficzne, przede wszystkim $\mathrm{z}$ zakresu teorii poznania oraz aksjologii ${ }^{13}$, ale także zaszczepił w nim ważną naukową dyrektywę - pociąg do podejmowania własnych rozstrzygnięć problemowych z równoczesnym zachowaniem szacunku dla różnorodności tendencji i stanowisk naukowych.

\footnotetext{
${ }^{10}$ Por. T. Pękala, Świat jako przedmiot estetyczny, s. XIV-XV.

${ }^{11}$ Materiały Archiwalne M. Wallisa..., teczka Rps 10, T. VI, k. 24.

12 Tamże, k. 25.

${ }^{13}$ Wallis podobnie jak późniejsi badacze i historycy filozofii, podkreślał, że Windelband pojmował filozofię jako naukę o wartościach absolutnych: logicznych (prawda), etycznych (dobro) i estetycznych (piękno). Por. tamże. Jak wyjaśnia T. Gadacz: „Windelband [...] dążył do stworzenia filozofii o inspiracji Kantowskiej, w której [...] położył akcent na problem wartości jako źródła i prawomocności bądź to poznania naukowego, bądź aktywności etycznej, bądź twórczości estetycznej”. A dalej: „Windelband dążył nie tylko do normującej teorii poznania, lecz także do pojęcia krytycznej filozofii jako nauki o najbardziej obowiązujących wartościach [...]". T. Gadacz, Historia filozofii XX wieku, s. 206, 225.
} 


\section{Mieczysław Wallis jako reprezentant szkoły lwowsko-warszawskiej}

Po powrocie do kraju, chcąc kontynuować edukację i rozwijać swe pasje intelektualne, Wallis zapisał się na nowo otwarty Uniwersytet Warszawski, gdzie w latach 1916-1921 studiował filozofię, a następnie obronił z niej doktorat ${ }^{14}$. To właśnie na Uniwersytecie Warszawskim poznał Jana Łukasiewicza oraz zetknął się z programem naukowym szkoły lwowsko-warszawskiej o zupełnie innym niż heidelberski nastawieniu metodologicznym. Sam Wallis zresztą dostrzegał i wielokrotnie podkreślał tę totalną odmienność postaw uczonych z obu ośrodków akademickich. Pisał o tym następująco:

Różnice klimatu intelektualnego, atmosfery filozoficznej między Heidelbergiem a Warszawą. Heidelberg - kult Kanta. Windelband był jednym z wybitnych przedstawicieli neokantyzmu [...]. Warszawa - Łukasiewicz wywodził się z zupełnie innej tradycji filozoficznej. Był uczniem K. Twardowskiego, który z kolei był uczniem Brentany. Brentano w filozofii Kanta widział "pomyłkę«. [...] Łukasiewicz był dalej wierzącym katolikiem, studiował $\mathrm{w}$ Lowanium u kard.[ynała] ${ }^{15}$ Merciera - stosunek katolicyzmu do (protestanckiej) filozofii Kanta z jej uznaniem czynnego, twórczego charakteru rozumu, był na wskroś negatywny. Wreszcie dzieła Kanta, podobnie zresztą jak innych filozofów, roiły się od błędów logicznych: rzecz niewybaczalna. Windelband był przeciwnikiem logiki matematycznej [...]. Łukasiewicz był entuzjastą logiki matematycznej i jej pionierem w Polsce ${ }^{16}$.

W odróżnieniu od szkoły badeńskiej przejawiającej kult Kanta i kładącej nacisk na aksjologiczny wymiar dociekań filozoficznych (filozofia była rozumiana tu jako nauka o ogólnoludzkich wartościach), naczelnym dążeniem szkoły Kazimierza Twardowskiego było zainicjowanie w Polsce filozofii naukowej, pozbawionej treści wartościujących, a uprawianej metodycznie, z zachowaniem ścisłych wymogów krytycyzmu naukowego ${ }^{17}$. Filozofia naukowa

\footnotetext{
${ }^{14}$ Por. Materiały Archiwalne M. Wallisa..., teczka Rps 10, T. I, k. 25-26, 15.

${ }_{15}$ Przypis własny.

16 Tamże, k. 34.

${ }_{17}$ Por. R. Jadczak, Seminarium filozoficzne Kazimierza Twardowskiego, „Edukacja Filozoficzna” 1989, vol. 9, s. 409. Dla Twardowskiego ważne było nie tylko to, jak uprawiać filozofię, ale także w jaki sposób ujmować i przekazywać jej treści. Stąd też głoszony przez niego radykalizm postulatu jasności w dyskursie filozoficznym. Por. J. Zegzuła-Nowak, Postulat jasności w po-
} 
miała więc być dyscypliną spełniającą określone wymogi formalne ${ }^{18}$. Wśród naczelnych dyrektyw głoszonych przez Twardowskiego, a z czasem przejętych przez jego najbliższych uczniów i współpracowników (m.in. Jana Łukasiewicza, Tadeusza Kotarbińskiego, Tadeusza Czeżowskiego, Kazimierza Ajdukiewicza, czy Władysława Witwickiego ${ }^{19}$ znalazły się zatem m.in. takie założenia jak: empiryzm metodologiczny, racjonalizm, postulaty jasności, ścisłości, precyzji terminologicznej, wyraźnego definiowania pojęć, usuwania wieloznaczności jako przyczyny nieporozumień słownych, przeciwstawiania się jałowej spekulacji, skrupulatnego, racjonalnego (popartego logiczną argumentacją) uzasadniania wygłaszanych twierdzeń, stosowanie metody analizy semantyczno-logicznej do rozstrzygania spornych zagadnień i rugowanie $\mathrm{z}$ dociekań filozoficznych treści niespełniających takich wymagań ${ }^{20}$.

Tak jednoznacznie i zdecydowanie sformułowany program naukowy szkoły lwowsko-warszawskiej nie pozostał bez wpływu na postawę naukowo-badawczą młodego Wallisa. Autorytet naukowy i charyzma mistrzów warszawskich nie tylko przyćmiły jego wcześniejsze predylekcje naukowe z okresu szkoły badeńskiej, ale także ukształtowały jego dalsze zainteresowania badawcze oraz warsztat naukowy.

Podobnie jak „twardowszczycy” Wallis w swej dalszej pracy naukowej konsekwentnie stosował analizę językową, przejawiał dbałość o czystość i poprawność językową, dążył do ścisłej precyzji terminologicznej i klasyfikacji pojęć, a także logicznego uzasadniania wygłaszanych twierdzeń ${ }^{21}$. Kierując się zaś postawą metodologicznego empiryzmu, odrzucał rozwiązania absolutystyczno-obiektywistyczne, jak też zdania o charakterze wartościującym,

lemikach metafilozoficznych Kazimierza Twardowskiego, „Analiza i Egzystencja” 2011, nr 16, s. 51-73.

${ }^{18}$ Por. J. Skoczyński, J. Woleński, Historia filozofii polskiej, Wyd. WAM, Kraków 2010, s. 440-441 .

${ }^{19}$ Por. tamże, s. 400-401.

${ }^{20}$ Por. K. Twardowski, Granice puryzmu, [w:] tenże, Rozprawy i artykuły filozoficzne, Wyd. Księgarnia Książnica-Atlas, Lwów 1927, s. 215-221; R. Jadczak, Rola Kazimierza Twardowskiego w stworzeniu analitycznej szkoły filozoficznej w Polsce, „Przegląd Filozoficzny” 1988, nr 11-12, s. 139.

${ }^{21}$ Por. T. Pękala, Świat jako przedmiot estetyczny, s. XVI oraz taż, Mieczysław Wallis (1895-1975), „Rocznik Historii Sztuki”, PAN, Warszawska Drukarnia Naukowa, Warszawa 2011, t. XXXVI, s. 70. 
powołując się w swych pracach na niezwykle rozległy i bogaty materiał m.in. historyczny, socjologiczny i artystyczny ${ }^{22}$.

Sam uczony zresztą, ceniąc i akcentując wpływ szkoły lwowsko-warszawskiej, szczególnie autora dzieła $O$ zasadzie sprzeczności u Arystotelesa na metodologię swej pracy naukowo-badawczej, pisał po latach następująco:

Moim mistrzom warszawskim w dziedzinie filozofii, Janowi Łukasiewiczowi i Tadeuszowi Kotarbińskiemu, oraz ich lwowskiemu nauczycielowi, Kazimierzowi Twardowskiemu, zawdzięczam dążenie do precyzyjnego rozróżniania i definiowania terminów, do największej poprawności w rozumowaniu, do możliwie najjaśniejszego formułowania myśli ${ }^{23}$.

Co ważne, być może to właśnie doświadczenia badawcze, które zebrał w warszawskim ośrodku naukowym uświadomiły młodemu Wallisowi, że filozofię można rozumieć i uprawiać na różne sposoby. Być może stały się także przyczynkiem do jego późniejszego nastawienia pluralistycznego, stanowiącego istotny rys jego koncepcji naukowych z zakresu estetyki i teorii sztuki.

\section{Jan Łukasiewicz jako człowiek i uczony we wspomnieniach Mieczysława Wallisa}

Jak wyraźnie wskazują Wallisowskie zapiski, największy wpływ z kręgu warszawskich uczonych na jego postawę naukowo-badawczą obok Tadeusza Kotarbińskiego, promotora jego rozprawy doktorskiej, wywarł niewątpliwie Jan Łukasiewicz ${ }^{24}$.

Uczony ten nie tylko przekazał mu najważniejsze postulaty metodologiczne dotyczące prowadzenia pracy badawczej, ale także ukształtował jego poglądy filozoficzne (przede wszystkim zmienił jego stosunek do Kanta) oraz

\footnotetext{
${ }^{22} \mathrm{Na}$ temat wpływu szkoły lwowsko-warszawskiej na poglądy i sposób prowadzenia pracy badawczej Wallisa zob. także J. Zegzuła-Nowak, Mieczysław Wallis i Henryk Elzenberg w estetyce polskiej XX wieku, „Edukacja Filozoficzna 2013, vol. 55, s. 67-68.

${ }^{23}$ M. Wallis, Przeżycie $i$ wartość: pisma $z$ estetyki nauki o sztuce 1931-1949, Wydawnictwo Literackie, Kraków 1968, s. 25.

${ }^{24} \mathrm{Z}$ kolei Jan Łukasiewicz był jednym z recenzentów rozprawy doktorskiej Wallisa (obok Władysława Witwickiego). Por. Materiały Archiwalne M. Wallisa..., Rps 10, T. I, k. 15.
} 
zainspirował go do sprecyzowania własnych dociekań intelektualnych. Dlatego też Wallis poświęcił swemu mentorowi wiele zapisków i wspomnień.

Swego warszawskiego nauczyciela Wallis opisywał następującymi słowy: „Jan Łukasiewicz pochodzenia ormiańskiego (?), wierzący katolik, mniej niż średniego wzrostu, raczej niepozorny brunet. Włosy krótko ostrzyżone, czarne, nieco szczurze oczy, iskrzące się, para pince-nez ${ }^{25}$, bródka, na ulicy nosił stale laskę, którą miarowo, rytmicznie podnosił i opuszczał, ubrany porządnie, lecz skromnie"26. To Łukasiewiczowskie połączenie skromnego wyglądu i zachowania $\mathrm{z}$ ogromną, niespotykaną siłą intelektu stanowiły w odczuciu Wallisa swoiste kuriozum, które ujmował w takich oto słowach:

Była dziwna rozbieżność między niepozornym wyglądem tego człowieka i statecznym, zrównoważonym sposobem bycia, a rewolucyjnością jego myśli, światłością jego koncepcji logiki wielowartościowej i jego demoniczną działalnością destrukcyjną w stosunku do wielkich systemów filozoficznych przeszłości ${ }^{27}$.

Wielkość intelektualna Łukasiewicza szła jednak niewątpliwie w parze z siłą i wrażliwością jego charakteru i osobowości. Wallisowskie wspomnienia ukazują go bowiem jako człowieka kierującego się w relacjach $\mathrm{z}$ innymi życzliwością, wyrozumiałością, empatią i zwykłą ludzką solidarnością. O tych przymiotach świadczy chociażby jego następująca wypowiedź:

W dwusetną rocznicę zgonu Leibniza [...] Łukasiewicz miał odczyt o nim w ówczesnym Towarzystwie Psychologicznym [...]. Po tym była dyskusja, w której dr Pręgowski, psychiatra, gwałtownie potępił filozofię Leibniza jako zbiór wymysłów bez żadnej wartości. Łukasiewicz odpowiedział mu spokojnie i z wielkim umiarem. Gdyśmy się rozchodzili, powiedziałem do Łukasiewicza: »Czemu Pan Profesor nie zmiażdżył doktora Pręgowskiego«? Na to Łukasiewicz: »Dr Pręgowski jest moim kolegą z Uniwersytetu Lwowskiego. Razem słuchaliśmy Twardowskiego. Dobrze, że tacy lekarze, jak on, w ogóle interesują się filozofią ${ }^{28}$.

Co ciekawe, Jacek J. Jadacki podkreśla też, że Łukasiewicza cechowały nie tylko wrażliwość moralna, inklinacja w kierunku dobra, ale także uznanie

\footnotetext{
${ }^{25} \mathrm{Z}$ jęz. fr. „binokle”.

${ }^{26}$ Tamże, Rps 10, T. IX, k. 67.

27 Tamże, k. 69.

${ }^{28}$ Tamże, k. 72.
} 
i podziw dla wartości piękna, zarówno w odniesieniu do tworów ludzkich, jak i przyrody ${ }^{29}$. Postawa ta była niewątpliwie ogniwem łączącym go z rozmiłowanym w sztuce Wallisem, dla którego dociekania naukowe dotyczące wszelkich przejawów piękna stanowiły osnowę zarówno jego pracy badawczej, jak i całego życia. Jak pisał Jerzy Pelc: „Umiłowanie rzeczy pięknych było treścią życia Mieczysława Wallisa; ich analiza, opis oraz interpretacja wypełniły Jego pięćdziesięcioletnie badania naukowe w zakresie estetyki, historii sztuki, teorii sztuki, i semiotyki sztuki" ${ }^{30}$. Stąd Wallis ostatecznie obrał własną ścieżkę naukową, nie podążył w kierunku uprawiania logiki matematycznej czy poszukiwania fundamentów naukowości w filozofii na drodze logistycznych analiz, a co byłoby zapewne naturalną kontynuacją zainteresowań badawczych jego mentora. Skupił się przede wszystkim na rozważaniach z zakresu ontologii i epistemologii wartości estetycznych oraz specyfiki ocen i przeżyć z tą sferą powiązanych. Dążył także do ufundowania nowej metody estetyki, ujmującej sztukę z semantycznego punktu widzenia ${ }^{31}$. O roli estetyki w jego pracy badawczej i twórczej pisze także uczennica filozofa Wanda Nowakowska: „Estetyka [...], uprawiana zarówno na niwie naukowej jak i dydaktycznej przez długie, długie lata łączyła się integralnie z Jego fascynacją zagadnieniami teorii i historii sztuki, a wszystko to - śmiem mniemać - wynikało z bardzo osobistego, najgłębiej tkwiącego w sercu i umyśle Profesora - urzeczenia Pięknem"32.

Mimo odmienności przedmiotów, celów i obszarów badawczych Wallis niezwykle cenił swego mistrza, przede wszystkim jako nauczyciela i intelektualistę. Chociaż należy podkreślić, że mimo uznania dla dokonań naukowych Łukasiewicza, Wallisowska postawa wobec niego nigdy nie była bezkrytyczna ani bałwochwalcza. Wallis wielokrotnie podkreślał bowiem nie tylko destrukcyjny dla filozofii klasycznej radykalizm i nieprzejednanie w jego nastawieniu metodologicznym, ale także swą opozycję wobec tak uprzywilejowanej pozycji logiki wśród nauk, jaką przyznawał jego mentor. Autor dzieła Przeżycie i wartość pisał następująco: „」an Łukasiewicz fanatyczny zwolennik jasności i ścisłości, pionier na naszym gruncie logiki matematycznej, pogromca Kanta

\footnotetext{
${ }^{29}$ J.J. Jadacki, P. Surma, Posłowie. Jan Łukasiewicz - osoba i dzieło, s. 113.

${ }^{30}$ J. Pelc, Wspomnienia pozgonne o Mieczysławie Wallisie..., s. 5.

${ }^{31}$ Więcej na temat orientacji naukowej Wallisa zob. T. Pękala, Mieczysław Wallis (1895-1975), s. $72-78$.

${ }^{32}$ W. Nowakowska, Profesor Mieczysław Wallis, s. 7.
} 
i Hegla, u których znajdował tylko błędy logiczne i którym odmawiał wszelkich zasług" ${ }^{33}$. Dalej pisał też:

Na gruncie warszawskim Łukasiewicz był, poczynając od chwili otwarcia nowo wskrzeszonego uniwersytetu (15.XI.1915), głównym zwolennikiem i propagatorem logiki matematycznej. Logika matematyczna nie była dla niego jednym z wielu kierunków logiki: była jedynie liczącą się, nowoczesną postacią logiki. Łukasiewicz widział w logice matematycznej najściślejszą z nauk i sądził, że dzięki niej będzie można nadać większą ścisłość wszystkim naukom. Co więcej, wierzył w to, że dzięki niej będzie można nadać wreszcie charakter naukowy filozofii, która jak dotąd była jedynie zbiorem nonsensów i błędów logicznych ${ }^{34}$.

Należy tu podkreślić, że to właśnie na tej podstawie Łukasiewicz poddał krytycznej ocenie całą dotychczasową filozofię, postulując potrzebę jej totalnej reformy na podstawie metody logiki matematycznej (dedukcyjną i aksjomatyczną). Łukasiewicz pisał: „Całą filozofię nowożytną opadła niemoc jasnego i ścisłego, naukowego myślenia" ${ }^{35}$. Stan filozofii przedkantowskiej określał jako: „z jednej strony fantastyczne rojenia, nie wytrzymujące krytyki naukowej, z drugiej radykalny, dogmatyczny nieuzasadniony sceptycyzm"36. Szczególnie silnie krytykował jednak samego Kanta, który choć dostrzegał jałowość, nicość i nieefektywność poznawczą ówczesnej filozofii (brak możliwości dojścia do prawd ostatecznych), to jednak nie rozpoznawał właściwego źródła tej niemocy, które Łukasiewicz upatrywał w nienaukowości metodologicznej. W mniemaniu autora książki O zasadzie sprzeczności u Arystotelesa sam Kant bowiem także filozofował nienaukowo. Przekonywał: „Gdy zbliżamy się do filozofii kantowskiej z wymaganiami krytyki naukowej, jak domek z kart rozpada się jej budowa. Na każdym kroku mętne pojęcia, niezrozumiałe zdania, nieuzasadnione twierdzenia, sprzeczności i błędy logiczne.

\footnotetext{
${ }^{33}$ Tamże, k. 65.

${ }^{34}$ Tamże, k. 87. Łukasiewicz postulował potrzebę zerwania z dotychczasową filozofią jako nieposługującą się metodami naukowymi i w związku z tym, pozbawioną wartości naukowej w tekście pt. O metodę w filozofii. Pisał: „Filozofowie, nawet najwięksi, w tworzeniu systemów filozoficznych nie posługują się metodą naukową. Pojęcia, których używają, są przeważnie niejasne i wieloznaczne, twierdzenia najczęściej niezrozumiałe lub nieuzasadnione, rozumowania prawie stale błędne”. Por. J. Łukasiewicz, O metodę w filozofii, „Przegląd Filozoficzny” 1928, R. 31, nr 1-2, s. 3.

${ }^{35}$ J. Łukasiewicz, Kant i filozofia nowożytna, „Wiadomości Literackie” 1924, nr 19, s. 1.

${ }^{36}$ Tamże.
} 
Nic nie zostaje, prócz kilku genialnych może pomysłów, surowy materiał, czekający na opracowanie naukowe" ${ }^{37}$.

W konsekwencji zatem Łukasiewicz zanegował całą wielowiekową tradycję filozoficzną. Jak zaznaczał Wallis: „Nic nie ostawało się pod obuchem jego krytyki. Z sadystyczną satysfakcją demaskował on błędy logiczne - niekonsekwencje, sprzeczności, niepoprawne rozumowania w systemach Spinozy, Kanta i wyprowadzał stąd wniosek, że są one pozbawione jakiejkolwiek wartości naukowej"38.

To nastawienie Łukasiewicza uznające za jedyne kryterium wartości systemów filozoficznych ich logiczną poprawność, a także przyznające logice prym w nauce spotkało się zresztą z opozycją wielu ówczesnych myślicieli ${ }^{39}$.

${ }^{37}$ Tamże. Por. także Materiały archiwalne M. Wallisa..., Rps 10, T. IX, k. 24.

${ }^{38}$ Materiały archiwalne M. Wallisa..., Rps 10, T. IX, k. 17. Łukasiewicz argumentował następująco: „Filozofowie, nawet najwięksi, w tworzeniu systemów filozoficznych nie posługują się metodą naukową. Pojęcia, których używają, są przeważnie niejasne i wieloznaczne, twierdzenia najczęściej niezrozumiałe lub nieuzasadnione, rozumowania prawie stale błędne”. Stąd też uważał, że: „Wszystkie te systemy filozoficzne posiadają zapewne niemałe znaczenie w dziejach myśli ludzkiej, mają nieraz wielką wartość estetyczną lub etyczną, zawierają nawet niektóre trafne, na intuicji oparte spostrzeżenia; wartości naukowej nie posiadają żadnej. Stąd pochodzi, że filozofia nie tylko nie doszła dotąd, jak inne nauki, do jakichś prawd ustalonych i powszechnie uznanych, ale nie zdobyła się nawet na ścisłe sformułowanie swych zagadnień." Dlatego postulował on całkowitą metodologiczną reformę w uprawianiu filozofii. Pisał: „Przyszła filozofia naukowa musi zacząć swą budowę od samego początku, od fundamentów. Zacząć zaś od fundamentów, to znaczy zrobić naprzód przegląd zagadnień filozoficznych i wybrać spośród nich te tylko zagadnienia, które można sformułować zrozumiale, odrzucić zaś wszelkie inne. [...] Następnie trzeba przystąpić do prób rozwiązania tych zagadnień filozoficznych, które można sformułować zrozumiale”. J. Łukasiewicz, O metodę w filozofii, „Przegląd Filozoficzny" 1928, R. 31, nr 1-2, s. 3-4.

${ }^{39}$ Jednym z nich, zaciekle broniącym metodologicznego pluralizmu w filozofii, był bliski przyjaciel Wallisa Henryk Elzenberg. Uważał on, że stawianie granic filozofii, czy to merytorycznych, czy metodologicznych, może znacząco zubożyć jej przedmiot i przyczynić się do jej stagnacji. Sam stosował różne sposoby i formy wyrażania treści filozoficznych (np. poetycką, aforystyczną, metaforyczną). Przejawiał też zdecydowanie odmienny aniżeli przyjęty przez Łukasiewicza stosunek do błędu i jego roli poznawczej. Przekonany był, że filozofia nie tylko nie może negować tego, co wykracza poza precyzyjne i ściśle naukowe metody weryfikacji, ale wręcz powinna przede wszystkim podejmować takie właśnie „oporne” problemy, gdyż to one są najczęściej najważniejsze dla człowieka. Pisał: „U podstaw metody, zalecanej przez prof. Łukasiewicza, zdaje się tkwić przecenianie szkodliwości błędu dla postępu wiedzy. Wszakże błędy mogą być i bywają korygowane; od błędu gorszy jest strach przed błędem, obezwładniający umysły i hamujący w ten sposób rozwój nauki”. P. Pręgowski, E. Erdmann, H. Jakubanis, J. Kopacz, A. Wiegner, B. Bornstein, W. Rubczyński, H. Elzenberg, C. Białobrzeski, Dyskusja, „Przegląd Filozoficzny” 1928, R. 31, nr 1-2, s. 7. 
Także Wallis przyznawał, że nie można oceniać dotychczasowych dokonań filozofów jedynie na podstawie naukowości ich koncepcji. Stąd zdecydowanie negował dyrektywy swego nauczyciela, uznając je za krzywdzące i deprecjonujące koncepcje filozoficzne, które dotychczas uznawano za wzniosłe i wartościowe. Postulaty Łukasiewicza uznał on nawet za swego rodzaju zamach na intelektualną spuściznę klasyków filozofii. O Łukasiewiczowskim programie metodologicznym pisał krytycznie w następujących zapiskach: „Poprawność logiczna stała się dla niego jedynym kryterium wartości systemów filozoficznych - w końcu widział on w tych systemach jedynie steki błędów logicznych. Wielkość jednostronności i jednostronność wielkości. Fanatyk ścisłości”" ${ }^{\prime 0}$. A dalej:

Dla Łukasiewicza każdy system filozoficzny musiał się przede wszystkim wylegitymować przed forum logiki ${ }^{41}$. I oto okazywało się, że »Etyka« Spinozy lub »Prolegomena« Kanta roją się od najbardziej elementarnych błędów logicznych - wieloznaczności, sprzeczności, błędnych kół w dowodzeniu... Pozbawiało to je, według Łukasiewicza, wszelkiej wartości. Systemy wielkich filozofów przeszłości były dla niego jedynie stekiem błędów logicznych ${ }^{42}$. Działanie destrukcyjne jego wykładów z historii filozofii było potężne. Odzierał on z blasku nazwiska wielkich filozofów przeszłości, które zwykliśmy wymawiać z czcią. Burzył autorytety. Tego, że te systemy były wspaniałymi wizjami świata i kondensacją bogatych doświadczeń życiowych wielkich osobowości, Łukasiewicz już nie dostrzegat ${ }^{43}$.

\section{IV. „Przewrót antykantowski” i zwrot ku metodologicznym postulatom uprawiania filozofii naukowej w postawie naukowej Mieczysława Wallisa}

Należy podkreślić jednak, że mimo zdecydowanego sprzeciwu wobec niezwykle radykalnego Łukasiewiczowskiego programu przebudowy filozo-

\footnotetext{
${ }^{40}$ Materiały Archiwalne M. Wallisa..., Rps 10, T. IX, k. 66.

${ }^{41}$ Fragment ten znajdujemy także w opracowaniu T. Pękali. Zob. taż, Świat jako przedmiot estetyczny, s. XVI.

${ }^{42}$ Por. J. Łukasiewicz, Kant i filozofia nowożytna, s. 1.

${ }^{43}$ Materiały Archiwalne M. Wallisa..., Rps 10, T. IX, k. 68. Materiały te omawia m.in. także T. Pękala. Zob. taż, Estetyka otwarta Mieczysława Wallisa, s. 7.
} 
fii przy użyciu niezawodnych narzędzi logicznych, Wallis przejął i rozwinął wiele jego postulatów metodologicznych (przede wszystkim dotyczących samego warsztatu naukowego) oraz merytorycznych (głównie z zakresu teorii poznania oraz metodologii filozoficznej). Rezerwuar uposażenia zadość czyniącego postulatom naukowego rygoryzmu metodologicznego, zaczerpnięty od swego mistrza, a rozciągający się na całą jego spuściznę intelektualną wyszczególnił w jednej ze swych rękopiśmiennych notatek, pisząc: „Analiza języka filozoficznego, dążenie do klasyfikacji pojęć, do sprecyzowania terminów - estetycznych (estetyczny, piękny, kontemplacja, sztuka); psychologicznych (objaw, wyraz, informacja, rozumienie); semiotycznych (znak, reprezentacja, symbol). Moja analiza struktury rozumowań, za pomocą których uzasadniamy oceny estetyczne, nawiązuje do dokonanego przez Jana Łukasiewicza rozróżnienia rozumowań dedukcyjnych i redukcyjnych" 44 .

Nauczył się także sztuki krytycznego myślenia i formułowania własnych sądów. Z pewnością także to swemu nauczycielowi zawdzięczał towarzyszące $\mathrm{mu} \mathrm{w}$ pracy badawczej przekonanie, zgodnie z którym proces zdobywania i rozwijania wiedzy nigdy nie może polegać jedynie na bezrefleksyjnym przyjmowaniu poglądów choćby i największych autorytetów (a takim był dlań niewątpliwie sam Łukasiewicz). Nieobce stało się mu zatem przekonanie, że wszelkie teorie, które zyskują nasze uznanie, powinny przekonywać nas siłą swej argumentacji, a więc posiadać odpowiednie uzasadnienie. Łukasiewicz wywarł także istotny wpływ na poglądy epistemologiczne Wallisa, a w szczególności na ewolucję jego stosunku do filozofii Kanta ${ }^{45}$.

Poglądy warszawskiego uczonego okazały się bowiem istotnym bodźcem dla Wallisa, by poszukiwać remedium, na trapiącą go jeszcze od czasów studiów w Heidelbergu bolączkę dotarcia do wiedzy pewnej i obiektywnej, a którą mógłby zarazem uczynić fundamentem własnych koncepcji twórczych. W swych zapiskach zatytułowanych Dzieje mego filozofowania Wallis

\footnotetext{
${ }^{44}$ Materiały Archiwalne M. Wallisa..., Rps 10, T. IX, k. 64. O wpływie intelektualnym Łukasiewicza na warsztat naukowy M. Wallisa pisze także T. Pękala, przytaczając prezentowany tu fragment archiwaliów. Zob. taż, Estetyka otwarta Mieczysława Wallisa, s. 8. Por. także: M. Wallis, Przeżycie i wartość..., s. 12, 26, 39-42 oraz T. Pękala, Świat jako przedmiot estetyczny..., s. 39-42.

${ }^{45}$ Problematykę wpływu J. Łukasiewicza na ewolucję stanowiska Wallisa dotyczącego koncepcji epistemologicznej I. Kanta analizuje przede wszystkim T. Pękala. Por. taż, The Aesthetics of Mieczysław Wallis, [w:] 20th Century Aesthestics in Poland Masters and Their Followers, ed. by K. Wilkoszewska, The Library of Art and Philosophy „Sztuka i Filozofia”, Wydawnictwo Naukowe Semper, Warszawa 2013, s. 174-175; taż, Estetyka otwarta Mieczysława Wallisa, s. 7-8; taż, Świat jako przedmiot estetyczny, s. 15-16.
} 
wyjaśniał następująco: „W latach 1912/16 przestudiowałem »Krytykę czystego rozumu« $\mathrm{i}$ »Prolegomena«. W okresie tym szukałem przede wszystkim wiedzy pewnej, pewności. Wyniki rozważań Kanta były przygnębiające: niemożność poznania »rzeczy samych $\mathrm{w}$ sobie ${ }^{46}$ «, ograniczenie wiedzy do wiedzy o »zjawiskach«. Lecz to przynajmniej wydawało się pewne i ta pewność czyniła dla mnie kantowską teorię poznania niezmiernie cennąa ${ }^{47}$. (Ponadto teza Kanta o niemożności naukowej wiedzy o rzeczach samych w sobie otwierała perspektywę dla wiary religijnej, czego podówczas byłem również spragniony)" 48 .

Po przeniesieniu się na Uniwersytet Warszawski w 1916 roku Wallis zyskał zatem możliwość spojrzenia na filozofię Kanta z innej perspektywy. Stopniowo chłonąc atmosferę naukową ośrodka warszawskiego i afirmowany tam kult naukowości, odrzucił neokantowski punkt widzenia z Heidelberga. Za Łukasiewiczem uznał, że filozofia Kantowska, redukująca teorię poznania do poznania matematycznego i przyrodniczego, stawiająca poznaniu ludzkiemu ścisłe granice i z góry skazująca uczonych na epistemologiczną porażkę, nie jest w stanie zaspokoić poznawczych pragnień człowieka. Zaznaczał też, że jako godząca w ideę wolnego niczym nieograniczonego, niepohamowanego rozwoju nauki, podważa też zasadność jej uprawiania. Pisał: „Zakreślanie z góry granic poznaniu ludzkiemu jest grzechem przeciw duchowi nauki, jest sprzeczne $z$ duchem nauki, antynaukowe. Takie twierdzenia jak teza Locke’a o niepoznawalności substancji lub teza Kanta o niepoznawalności rzeczy samych w sobie [...] są sprzeczne $\mathrm{z}$ duchem nauki, hamują postęp nauki ${ }^{49}$. Taką była główna myśl jednego $\mathrm{z}$ wykładów Łukasiewicza $\mathrm{z}$ »teorii poznania« [...], który zrobił na mnie szczególnie duże wrażenie"50.

Będąc pod wpływem wiedzy, argumentacji i nauczycielskiego autorytetu Łukasiewicza Wallis zatem definitywnie odrzucił filozofię kantowską, którą

\footnotetext{
${ }^{46}$ Fragment ten przywołuje i omawia także T. Pękala. Zob. taż, Estetyka otwarta Mieczysława Wallisa..., s. 6.

${ }^{47} \mathrm{~W}$ innej notatce Wallis podkreślał z mocą: „Kantowska teoria poznania, zwłaszcza teza o niepoznawalności rzeczy samych w sobie przygnębiała mnie swą treścią. Okropną była dla mnie myśl, że jesteśmy skazani na wyłączne poznawanie zjawisk i że w żaden sposób nie możemy wyjść poza nie”. Materiały Archiwalne M. Wallisa..., Rps 10, T. IX, k. 19. Także i tę wypowiedź Wallisa przywołuje i rozważa T. Pękala. Zob. taż, Świat jako przedmiot estetyczny..., s. XIV oraz Estetyka otwarta Mieczysława Wallisa..., s. 7.

${ }^{48}$ Materiały Archiwalne M. Wallisa..., Rps 10, T. IX, k. 17.

${ }^{49}$ Por. J. Łukasiewicz, Kant i filozofia nowożytna, s. 1.

${ }^{50}$ Materiały Archiwalne M. Wallisa..., Rps 10, T. IX, k. 84. Zob. także: T. Pękala, Świat jako przedmiot estetyczny..., s. XV.
} 
dotychczas postrzegał jako najwłaściwszą drogę snucia refleksji epistemologicznej i remedium na poznawcze rozterki.

Z czasem sformułował także własne stanowisko krytyczne, które pierwszą swą odsłonę znalazło w referacie pt. Kryteria poznania apriorycznego u Kanta wygłoszonym na seminarium u Łukasiewicza ${ }^{51}$.

Jego ukonstytuowanie się opisywał następująco:

Memu kantyzmowi zadał cios śmiertelny Łukasiewicz. Wysuwał on przeciw epistemologii Kanta zwłaszcza dwa zarzuty: 1) rozumowanie Kanta, wychodzące z faktu istnienia sądów syntetycznych a priori, jest rozumowaniem redukcyjnym, rozumowaniem przebiegającym od następstw do racji: rozumowanie takie nigdy nie daje wyników pewnych; 2) można kwestionować samą tezę, że sądy matematyczne są sądami syntetycznymi: według badań współczesnych, np. Russella, są one sądami analitycznymi, wynikającymi z przyjętych definicji. Do tego dodałem jeszcze zarzut następujący, co do którego nie wiem, czy pochodził on jeszcze od Łukasiewicza, czy nie: aby stwierdzić, iż rzeczy same w sobie, przechodząc przez nasz umysł, ulegają zniekształceniu, musielibyśmy zająć stanowisko obserwatora, któremu dostępne są rzeczy same w sobie, nasz umysł i to, co powstaje po przejściu rzeczy samych w sobie przez nasz umysł, co przecież właśnie według Kanta, jest niemożliwe ${ }^{52}$.

Wallis nie ograniczył się jednak tylko do krytycznej analizy epistemologicznej koncepcji filozofa z Królewca. „Zwrot antykantowski” w jego rozważaniach stał się bowiem istotnym przyczynkiem do podjęcia próby sformułowania własnego stanowiska w kwestii poszukiwania fundamentów poznania.

Wallis uznał bowiem, że wyniki dotychczasowych nauk ścisłych dotyczące możliwości poznania rzeczywistości są niewystarczające i dalece nie satysfakcjonujące poznawczo. Stąd też postanowił poszukiwać fundamentów poznawczych na drodze nauk humanistycznych ${ }^{53}$. Wychodząc od epistemo-

${ }^{51}$ Tekst ten nie został opublikowany, jednakże w archiwaliach Wallisa znajduje się notatka o tymże tytule datowana na 1917 rok, stanowiąca jeśli nie dosłowną treść wystąpienia, to zapewne wypis jego głównych tez. Autor krytykuje tu kantowskie epistemologiczne kryteria zdań apriorycznych - ścisłą powszechność i konieczność. Por. Materiały Archiwalne M. Wallisa..., Rps 10, T. IX, k. 25.

${ }^{52}$ Materiały Archiwalne M. Wallisa..., Rps 10, T. IX, k. 21.

${ }^{53}$ Wallis, rozumiejąc humanistykę jako zespół dziedzin badawczych w swym przedmiocie i metodologii odmiennych od nauk przyrodniczo-matematycznych, określał ją jako dziedzinę umysłową, „w której, po większej części nie tworzono uogólnień, nie szukano praw, nie przewidywano zdarzeń przyszłych, lecz w której także obserwowano, rozumowano, tworzono hipotezy, spierano się o wyjaśnienie tego lub innego faktu”. Do nauk humanistycznych zaliczał 
logii filozofa z Królewca poprzez inspirację filozofią autora „Budowy świata historycznego w naukach humanistycznych” konstatował następująco: „Według Kanta wszelkie poznanie dotyczy tylko zjawisk, nigdy rzeczy samych w sobie. Ale Kant badał tylko poznanie matematyczne i przyrodnicze. Może humanistyka jest w lepszej sytuacji? Może jest ona bliższa rzeczywistości niż przyrodoznawstwo? Może poznanie humanistyczne dociera do rzeczywistości takiej, jaką ona jest? Myśl tę znalazłem u Diltheya" ${ }^{54}$.

Ostateczną próbę odpowiedzi na pytanie o możliwość poznania istoty rzeczywistości Wallis zawarł w swej rozprawie doktorskiej pt. Obrona humanistyki $w$ metodologii współczesnej ${ }^{55}$. Jako punkt wyjścia swej tezy, założył, że nic nie stoi na przeszkodzie, by naukom humanistycznym przyznać status naukowości nie mniejszy aniżeli naukom ścisłym, zaznaczając zarazem ich specyfikę i autonomię zarówno co do przedmiotu, jak i metodologii ${ }^{56}$. Pisał: „usiłowałem uzasadnić tezę, że humanistyka jest w równej mierze nauką jak przyrodoznawstwo nie przez wykazanie, że humanistyka jest równie doskonała jak przyrodoznawstwo, lecz przez wykazanie, że przyrodoznawstwo jest równie niedoskonałe jak humanistyka" ${ }^{\text {"57 }}$.

Konsekwencją tego nastawienia metodologicznego była zatem próba uzasadnienia naukowego statusu nauk humanistycznych, a także uznania wartości poznawczej jej wyników ${ }^{58}$. W swej rozprawie doktorskiej Wallis, rozważając ontologiczne założenia wybranych koncepcji twórczych (m.in. Wundta, Diltheya, Wildelbanda), starał się określić ich wpływ na ogólną teorię wie$\mathrm{dzy}^{59}$. Dążył bowiem, by wykazać, że nauki o świecie ludzkiego ducha są bliż-

zaś dziedziny badań nad językiem, sztuką, religią, prawem, państwem. M. Wallis, Obrona humanistyki w metodologii współczesnej, „Przegląd Filozoficzny” 1922, R. 25, z. 1, s. 98.

${ }^{54}$ Materiały Archiwalne M. Wallisa..., Rps 10, T. IX, k. 22. Wypowiedź tę cytuje i omawia także T. Pękala. Zob. taż, Estetyka otwarta Mieczysława Wallisa, s. 7.

${ }^{55}$ Jak podaje sam autor, część historyczna rozprawy została opublikowana w „Przeglądzie Filozoficznym” w 1922 roku, natomiast jej istotniejsza zapewne - część krytyczna, w której uczony starał się uzasadnić tezę o naukowości humanistyki, pozostała w rękopisie i zaginęła podczas II wojny światowej. Por. Materiały Archiwalne M. Wallisa..., Rps 10, T. IX, k. 13, 28.

${ }^{56}$ Por. M. Wallis, Obrona humanistyki w metodologii współczesnej, s. 99.

${ }^{57}$ Materiały Archiwalne M. Wallisa..., Rps 10, T. IX, k. 13.

${ }^{58}$ Por. K. Rosner, Poglady estetyczne Mieczysława Wallisa. Badania estetyczne a inne dziedziny jego działalności naukowej i krytycznej, [w:] S. Krzemień-Ojak, W. Kalinowski (red.), Studia $z$ dziejów estetyki polskiej 1918-1939, PWN, Warszawa 1975, s. 158.

${ }^{59}$ Por. T. Pękala, Świat jako przedmiot estetyczny..., s. XV. 
sze istoty rzeczywistości aniżeli nauki o świecie liczb i materii ${ }^{60}$. Problematyka ta zainspirowała go także do próby ujęcia samej ogólnej klasyfikacji nauk. Pisał: „Zainteresowałem się metodami tych dyscyplin [historyczno-humanistycznych - przyp. własny] nie jako historyk, którego ciekawią metody uprawianej przez niego nauki, lecz jako myśliciel, który pragnie dociec, czy metody te mogą nam dać głębsze wejrzenie w rzeczywistość niż metody fizyki lub biologii”' ${ }^{61}$ W swej obronie statutu naukowości nauk humanistycznych posługiwał się argumentami, które przedstawiał następująco: „Moja obrona naukowości dyscyplin historyczno-humanistycznych szła po liniach następujących. Postawa indywidualizująca tych dyscyplin nie może przemawiać przeciw ich naukowości, albowiem wtedy musielibyśmy odmówić charakteru naukowego również indywidualizującym dyscyplinom przyrodniczym, jak np. geografia lub selenografia. To samo dotyczy niepewności twierdzeń historycznych: uogólnienia przyrodoznawstwa otrzymane dzięki indukcji niezupełnej też nigdy nie są pewne" ${ }^{\prime 2}$. Wallis szczególnie afirmował koncepcję Dilthey’a, który pojmując humanistykę jako zespół nauk o świecie dziejowo-społecznym, sferze ducha dowodził o wyższości poznania ludzkiego na tej drodze nad poznaniem zogniskowanym wokół zewnętrznego świata materii. Autor dzieła Przeżycia i wartość doniosłość i inspirującą dlań rolę tej koncepcji ujmował następująco:

W naukach o duchu wiemy, rozumiemy wpierw, nim poznajemy. Przedmiotem ich jest posiadana przez nas od samego początku w bezpośredniej wiedzy i w rozumieniu całość [...]; rozumiemy tutaj przedmiot, zanim go poznamy. Świat dziejowo-społeczny jest zrozumiały i przejrzysty dla ducha: jest on prze-

${ }^{60}$ Założenie to wyjaśniał następująco: „Szukałem poprzez humanistykę drogi do rzeczywistości, do »rzeczy samych w sobie«, których, jak mniemałem, wraz z Kantem, są niedostępne poznaniu matematyczno-przyrodniczemu. Dotąd żywię przekonanie, że humanistyka, mająca do czynienia z ludźmi, których życie psychiczne rozumiemy, przez analogię do naszego życia psychicznego, jest bliższa rzeczywistości niż przyrodoznawstwo [...]. Świat ludzki jest dla nas bardziej zrozumiały niż świat materii”. Materiały Archiwalne M. Wallisa..., Rps 10, T. IX, k. 11.

${ }^{61}$ Tamże, k. 3. W kolejnej notatce wyjaśniał w podobnym tonie, pisząc: „Szukałem poprzez humanistykę drogi do rzeczywistości, do »rzeczy samych w sobie«, które, jak mniemałem wraz z Kantem, są niedostępne poznaniu matematyczno-przyrodniczemu. Dotąd żywię przekonanie, że humanistyka, mająca do czynienia z ludźmi, których życie psychiczne rozumiemy poprzez analogię do naszego życia psychicznego, jest bliższa rzeczywistości niż przyrodoznawstwo, nauka o obcej nam materii, $\mathrm{z}$ jego hipotezami i wzorami matematycznymi (co nie pomniejsza jej skuteczności działania w tym świecie materii)”. Tamże, k. 11.

${ }^{62}$ Tamże, k. 12. 
cież z tego samego tworzywa, co duch, który go poznaje. Natomiast przyroda jest dla nas czymś obcym [...]; dlatego też jest ona nieprzenikliwa dla ducha, oporna w stosunku do jego wysiłków badawczych ${ }^{63}$.

Nie ma tu więc tak daleko idącej dystynkcji pomiędzy podmiotem i przedmiotem poznania, która za Dilthey’em jawiła się Wallisowi jako jedna z niemożliwych do przekroczenia barier i naczelne źródło negatywnych wyników poznawczych nauk przyrodniczych. Wallis zatem, poszukując wiedzy pewnej, drogi wyjścia poza Kantowski świat zjawisk, postanowił nie tyle zmienić samą metodologię naukową, ile zacząć od przedmiotu poznania, ze świata materii, przyrody wkraczając do świata tworów zatopionych, czy wręcz powstających w świecie ludzkim i stąd jedynie takową drogą poznawalnych drogą nauk o duchu - nauk humanistycznych. Jest to zapewne pociecha połowiczna, także i w odczuciu samego autora, jednakże jest o tyle cenna, że niesie człowiekowi epistemologiczną otuchę, na którą wskazywali już Sokrates i Kartezjusz, zaznaczając, że najważniejszym przedmiotem poznania jest on sam i to, co tworzy, kreuje, przetwarza. Stąd zrozumiały wydaje się dalszy krok w intelektualnej drodze Wallisa - zwrot ku światu tworów estetyki i historii sztuki, którego zgłębianiu poświęcił on całe swe dojrzałe intelektualne życie.

\section{Konkluzja}

Mieczysław Wallis był uczonym, który przez dziesięciolecia z ogromnym zaangażowaniem i konsekwencją rozwijał swe koncepcje twórcze. Szlif naukowy (metodologiczny i merytoryczny), jaki zdobył pod opieką dydaktyczną Jana Łukasiewicza, okazał się niezwykle wartościową schedą intelektualną i trwale zaważył na jego podejściu do nauki oraz sposobie jej uprawiania. Mimo bowiem, że ostatecznie jego predylekcje naukowe okazały się odmienne w stosunku do zainteresowań jego mistrza (zogniskowały się wokół problematyki estetycznej i nauk o sztuce), to pozostał on wierny jego wielu ważnym postulatom naukowym. Dbał o jasność i klarowność swego wywodu, niestrudzenie dążył do ukazania prawdy obiektywnej stanowiącej w jego aktywności naukowo-badawczej wartość nadrzędną, wytrwale szukał

${ }^{63}$ M. Wallis, Obrona humanistyki w metodologii współczesnej, s. 108. 
uzasadnień dla głoszonych poglądów, a także stale przejawiał troskę o swój intelektualny rozwój. Mając stale w poważaniu inspirującą postawę swego nauczyciela, dbał o to, by nie tylko rozwijać własne zdolności naukowe, ale także, by z życzliwą troską przekazywać zdobytą wiedzę kolejnym pokoleniom uczonych. Sam uczony, jako historyk sztuki i dydaktyk, pisał o swej służbie naukowej następująco:

Historyk sztuki pragnie poznać dzieje i poszczególne wybitne dzieła sztuki. Dzieła sztuki są tworzone po to, by dawały ludziom radość. Historyk sztuki obcując z wybitnymi dziełami sztuki [...] przeżywa przynajmniej cząstkę tej radości, jaką przeżywali ci, dla których te dzieła były stworzone. Otóż tej radości nie powinien on chować tylko dla siebie. Powinien on podzielić się nią z innymi, powinien przekazywać ją - przy pomocy słowa mówionego lub pisanego innym. Historyk sztuki powinien starać się przelać w innych entuzjazm dla sztuki, jaki ma sam. Tak przynajmniej pojmuję jedną z misji historyka sztuki ${ }^{64}$.

\section{Bibliografia}

Białostocki J., Wspomnienie pośmiertne. Mieczysław Wallis 1895-1975 (Przemówienie wygłoszone nad grobem $w$ dniu 30 października 1975 r.), [w:] M. Wallis, Sztuki i znaki. Pisma semiotyczne, PIW, Warszawa 1983.

Gadacz T., Historia filozofii XX wieku. Nurty, t. 2, Wyd. Znak, Kraków 2009.

Intymny portret uczonych. Korespondencja Marii i Stanisława Ossowskich, wybór, oprac. i wprow. E. Neyman, Wyd. Sic!, Warszawa 2002.

Jadacki J., Surma P., Posłowie. Jan Łukasiewicz - osoba i dzieło, [w:] J. Łukasiewicz, Pamiętnik, Wyd. Semper, Warszawa 2013.

Jadczak R., Rola Kazimierza Twardowskiego w stworzeniu analitycznej szkoły filozoficznej w Polsce, „Przegląd Filozoficzny” 1988, nr 11-12.

Jadczak R., Seminarium filozoficzne Kazimierza Twardowskiego, „Edukacja Filozoficzna" 1989, vol. 9.

Łukasiewicz J., Kant i filozofia nowożytna, „Wiadomości Literackie” 1924, nr 19.

Łukasiewicz J., O metodę w filozofii, „Przegląd Filozoficzny”, R. 31, 1928, nr 1-2.

Nowakowska W., Sylwetki łódzkich uczonych. Profesor Mieczysław Wallis, Łódzkie Towarzystwo Naukowe, zeszyt 59, Łódź 2001.

Pelc J., Wspomnienia pozgonne o Mieczystawie Wallisie i Tadeuszu Wójciku, „Studia Semiotyczne" 1977, $\mathrm{nr} 7$.

${ }^{64}$ Materiały Archiwalne M. Wallisa..., Rps 8, k. 111. 
Pękala T., Estetyka otwarta Mieczysława Wallisa, Wyd. Instytut Kultury, Warszawa 1997.

Pękala T. Mieczystaw Wallis, (1895-1975), ,Rocznik Historii Sztuki”, PAN, Warszawska Drukarnia Naukowa, Warszawa 2011, t. XXXVI.

Pękala T., Świat jako przedmiot estetyczny. Wprowadzenie, [w:] M. Wallis, Wybór pism estetycznych, Towarzystwo Autorów i Wydawców Prac Naukowych Universitas, Kraków 2004.

Pękala T., The Aesthetics of Mieczysław Wallis, [w:] 20th Century Aesthestics in Poland Masters and Their Followers, edited by K.Wilkoszewska, The Library of Art and Philosophy "Sztuka i Filozofia", Wydawnictwo Naukowe Semper, Warszawa 2013.

Pręgowski P., Erdmann E., Jakubanis H., Kopacz J., Wiegner A., Bornstein B., Rubczyński W., Elzenberg H., Białobrzeski Cz., Dyskusja, „Przegląd Filozoficzny", R. 31, 1928, nr 1-2.

Rosner K., Poglady estetyczne Mieczysława Wallisa. Badania estetyczne a inne dziedziny jego działalności naukowej i krytycznej, [w:] S. Krzemień-Ojak, W. Kalinowski (red.), Studia z dziejów estetyki polskiej 1918-1939, PWN, Warszawa 1975.

Skoczyński J., Woleński J., Historia filozofii polskiej, Wyd. WAM, Kraków 2010.

Twardowski T., Granice puryzmu, [w:] tenże, Rozprawy i artykuły filozoficzne, Wyd. Księgarnia Książnica-Atlas, Lwów 1927.

Wallis, Obrona humanistyki w metodologii wspótczesnej, „Przegląd Filozoficzny”, R. 25, 1922, z. 1.

Wallis M., Przeżycie i wartość: pisma z estetyki nauki o sztuce 1931-1949, Wyd. Literackie, Kraków 1968.

Zegzuła-Nowak J., Mieczysław Wallis i Henryk Elzenberg w estetyce polskiej XX wieku, „Edukacja Filozoficzna”, vol. 55, 2013.

Zegzuła-Nowak J., Postulat jasności w polemikach metafilozoficznych Kazimierza Twardowskiego, „Analiza i Egzystencja” 2011, nr 16.

\section{Archiwalia}

Materiały Archiwalne M. Wallisa, Archiwum Połączonych Bibliotek Wydziału Filozofii i Socjologii UW, Instytutu Filozofii i Socjologii PAN oraz Polskiego Towarzystwa Filozoficznego, teczki: Rps 8, Rps, 10, T. I, VI, IX. 


\section{Abstract \\ Jan Łukasiewicz as a Teacher, Mentor and Inspirer of Mieczysław Wallis' Creativeness}

Archive materials of Mieczysław Wallis are in the collection of the Joined Libraries of Philosophy and Sociology Faculties of the University of Warsaw, the Institute of Philosophy and Sociology of the Polish Academy of Science and the Polish Philosophy Society. Among them, there are some files devoted to his academic teacher, Jan Łukasiewicz. They contain a rich historical material, not published before and not known to many people. It is a valuable source of knowledge in the field of the history of Polish philosophy of the 20th century. Wallis's memoirs provide a lot of unique informations both on their mutual relationship, Łukasiewicz's personality, appearance, and scientific conceptions, as well his influence on Wallis's intellectual evolution.

Keywords: Mieczysław Wallis, Jan Łukasiewicz, neo-Kantianism, epistemology, history of Polish philosophy of the 20th century 